\title{
Acute tubulointerstitial nephritis and uveitis syndrome in the elderly
}

\author{
P Salu, N Stempels, K Vanden Houte, D Verbeelen
}

\begin{abstract}
A case of acute tubulointerstitial nephritis and uveitis syndrome (TINU syndrome) in an elderly woman is reported. The present case demonstrates that this entity originally observed in children, and more recently in adults, may also occur in the elderly. The aetiology and treatment are briefly discussed.
\end{abstract}

In December 1985 a 66-year-old Caucasian woman complained of symptoms of anorexia and fatigue. A clinical examination gave normal results. Her blood urea was $8 \mathrm{mmol} / \mathrm{l}$ and serum creatinine $133 \mu \mathrm{mol} / \mathrm{l}$. A proteinuria of $0.9 \mathrm{~g} / \mathrm{l}$ and some leucocytes in the urine were found. An $x$-ray of the chest, barium meal $x$-ray bone scintigraphy, and abdominal echography were normal.

Renal symptoms. One month later admission was necessary because of acute renal failure. Her blood pressure was $190 / 100 \mathrm{mmHg}$ and temperature $37 \cdot 4^{\circ} \mathrm{C}$. A clinical examination did not reveal other abnormalities. The evolution of the positive blood tests is shown in Table 1. Serological markers for cytomegalovirus, hantavirus, hepatitis B virus antigen, syphilis, streptococci, rubella, salmonella, toxoplasmosis, EpsteinBarr virus, and herpes simplex virus, as well as repeated blood cultures, tests for rheumatoid arthritis factor, immune complexes, and Coombs's reaction were negative. The patient had not been exposed to toxic agents and denied the use of analgesics, antibiotics, or other drugs.

A renal biopsy was carried out. The proximal and distal tubules showed focal areas of destruction, and the interstital tissue was swollen by oedema and a dense infiltrate of lymphocytes, plasmocytes, neutrophils, and some eosinophils; small blood vessels had a swollen endothelium. Immunofluorescence showed the presence of complement in the endothelial layer of the small vessels and protein casts in the tubules (Figs 1 and 2).

Idiopathic acute tubulointerstitial nephritis (AIN) was diagnosed and oral treatment of methylpredisone (32 $\mathrm{mg} /$ day) was started. Corticosteroid treatment was gradually decreased and stopped in April 1986. The results of follow-up blood and urine examinations progressively returned to normal (Table I and Fig 3).

Ocular symptoms. In June, 5 months after the beginning of the acute renal failure, the patient complained of itching, redness, and pain in the left eye. She was treated with local antibiotic eye drops of Chloransulfa (chloramphenicol $5 \mathrm{mg}$, sodium sulphacetamide $100 \mathrm{mg} / \mathrm{ml}$, collyrium 10 $\mathrm{ml}$ ). Two weeks later she complained of loss of vision in the left eye. The visual acuity was $6 / 6$ in the right eye and 6/12 in the left eye. The anterior segment showed keratic precipitates, Tyndall positivity, and posterior synechiae in the left eye. The inferior fornix was hyperaemic, with secretions and follicles. The intraocular pressure was normal. The diagnosis of anterior uveitis was made. Topical treatment of combined neomycin sulphate, polymyxin $B$, and dexamethasone drops (Maxitrol) together with atropine $1 \%$ was started. Two days later persistent posterior synechiae were successfully treated with a paralimbal injection of $0 \cdot 1 \mathrm{ml}$ of adrenaline $(0 \cdot 1 \%)$. Ten days later the visual acuity of the left eye had increased to 6/9. The treatment with Maxitrol eye drops was discontinued because of increasing intraocular pressure. Twenty months later the patient developed a moderate anterior uveitis in the right eye, with a slight Tyndall positive reaction. This inflammatory reaction resolved completely after a few days of treatment with steroid eye drops (Maxitrol). Classical tests for uveitis remained negative.

\section{Discussion}

Since 1975 several cases of an association of acute interstitial nephritis (AIN) with uveitis without any obvious aetiology have been described in children. ${ }^{1-12}$ Later a few cases of this oculorenal syndrome have been reported in adult females. ${ }^{10-14}$ (Table II). Eighteen out of 28 patients were younger than 20 and the oldest was 56. Our case illustrates that this syndrome can appear at any age. It is interesting to note that the uveitis may appear before, simultaneously with, or after the renal failure. The uveitis appeared as a first symptom in only three cases and simultaneously with the nephritis in five cases. The uveitis was preceded by AIN in 18 cases, with an interval of two to seven months. In 17 cases $(70 \%)$ the two eyes were involved within two months. In the present case the contralateral eye was involved after 20 months.

In general the anterior uveitis responds well to topical corticosteroid treatment, as the present case confirms. Good results in the treatment of

TABLE I Evolution of blood and urine analysis data during and after $A I N$

\begin{tabular}{|c|c|c|c|}
\hline & fan 1986 & Feb 1986 & May 1986 \\
\hline $\operatorname{ESR}(\mathrm{mm} / \mathrm{l} \mathrm{h})$ & 70 & 36 & 13 \\
\hline Haemoglobin $(\mathrm{g} / \mathrm{dl})$ & $12 \cdot 6$ & $9 \cdot 4$ & $12 \cdot 7$ \\
\hline Leucocytosis $\left(\times 19^{9} / 1\right)$ & $9 \cdot 3$ & 9.6 & $4 \cdot 0$ \\
\hline Neutrophils (\%) & 57 & 65 & 48 \\
\hline Eosinophils (\%) & 3 & 6 & 6 \\
\hline Lymphocytes (\%) & 39 & 20 & 29 \\
\hline Blood urea $(\mathrm{mmol} / \mathrm{l})$ & 18 & 12 & 10 \\
\hline Blood creatinine $(\mu \mathrm{mol} / \mathrm{l})$ & 592 & 194 & 141 \\
\hline $\begin{array}{l}\text { Creatinine clearance } \\
\left(\mathrm{ml} / \mathrm{min} / 1.73 \mathrm{~m}^{2}\right)\end{array}$ & $8 \cdot 2$ & & \\
\hline Proteinuria (g/l) & 0.5 & $0 \cdot 5$ & $1 \cdot 0$ \\
\hline Glucosuria $(\mathbf{g} / \mathbf{l})$ & $3 \cdot 2$ & $2 \cdot 5$ & $1 \cdot 2$ \\
\hline
\end{tabular}

Correspondence to: Dr P Salu, Academisch Ziekenhuis, Vrije Universiteit Brussel, Laarbeeklaan 101, 1090 Brussels, Belgium.

Accepted for publication 21 July 1989 
Figure 1: Photomicrograph of renal biopsy showing normal glomerulus, normal blood vessel, and interstitial infiltrate consisting of

inflammatory cells. (PAS, $\times 200$.)

Figure 2: Photomicrography of the renal biopsy showing the inflammatory infiltrate composed of lymphocytes, plasmocytes, neutrophils, and some eosinophils

(indicated by arrows). (PAS, ×320.)
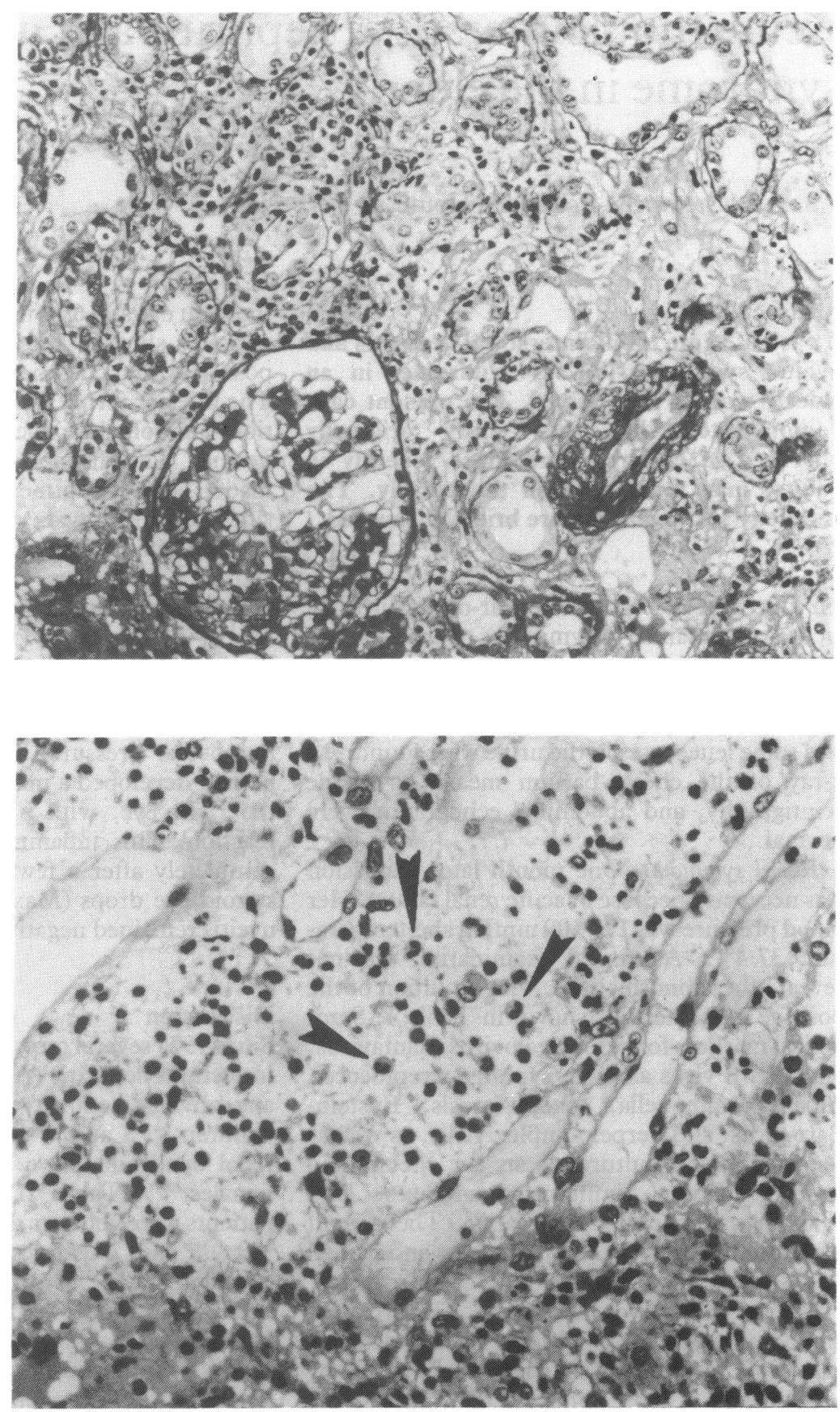

Figure 3: Clinical course of AIN and uveitis.

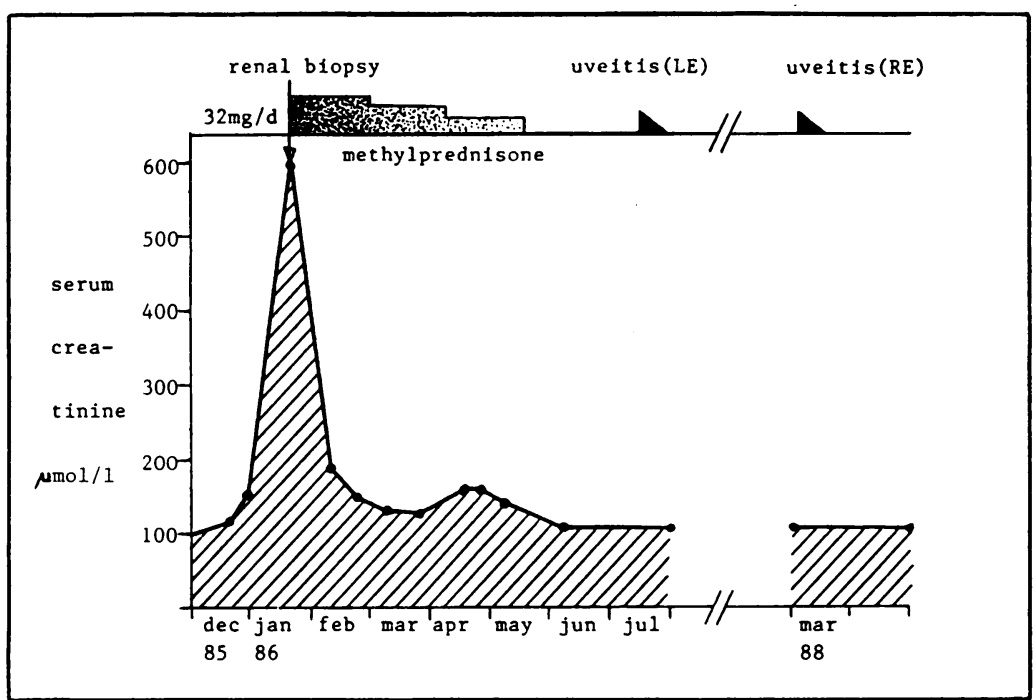


TABLE II Uveitis in TINU syndrome

\begin{tabular}{|c|c|c|c|c|c|c|c|}
\hline \multirow[b]{2}{*}{ Author } & \multirow[b]{2}{*}{ Year } & \multirow[b]{2}{*}{ Sex } & \multirow[b]{2}{*}{ Age } & \multicolumn{4}{|c|}{ Uveitis } \\
\hline & & & & Ant. & Post. & $U n i t / b i^{\star}$ & Monthst \\
\hline \multirow[t]{2}{*}{ Dobrin et al ${ }^{1}$} & 1975 & $\mathrm{~F}$ & 14 & + & - & bi & +3 \\
\hline & & $\mathrm{F}$ & 17 & - & - & bi & 0 \\
\hline \multirow[t]{2}{*}{ Guesry and Loirat ${ }^{2}$} & 1976 & $\begin{array}{l}M \\
F\end{array}$ & $\begin{array}{l}11 \\
10\end{array}$ & & & & $\begin{array}{l}<1 \\
+2\end{array}$ \\
\hline & & $\mathrm{F}$ & 14 & & & & $<1$ \\
\hline \multirow{2}{*}{ Kikkawa $e t a l^{3}$} & 1977 & $\mathbf{F}$ & 13 & + & - & bi & +1 \\
\hline & & $\mathbf{F}$ & 14 & + & - & bi & $<1$ \\
\hline Van Acker $e t a l^{4}$ & 1980 & $\mathbf{F}$ & 14 & + & - & bi & +2 \\
\hline \multirow[t]{2}{*}{ Levy } & 1983 & $\mathbf{F}$ & $\begin{array}{l}\text { id } \\
10\end{array}$ & - & + & & +3 \\
\hline & & M & 13 & & & & \\
\hline \multirow{2}{*}{$\begin{array}{l}\text { Roth and Laberke } \\
\text { Burghard et al }\end{array}$} & 1983 & $\mathbf{M}$ & 15 & + & $+\ddagger$ & uni & 0 \\
\hline & 1984 & $\mathbf{F}$ & $\begin{array}{l}14 \\
11\end{array}$ & $\begin{array}{l}+ \\
+\end{array}$ & $\overline{-}$ & $\begin{array}{l}\text { bi } \\
\text { bi }\end{array}$ & $\begin{array}{r}0 \\
+3\end{array}$ \\
\hline \multirow{6}{*}{$\begin{array}{l}\text { Steinman and Silva } \\
\text { Vanhaesebrouck et } a^{8} \\
\text { Leumann } \text { et }^{8} l^{9} \\
\text { Noël } \text { et } a l^{10}\end{array}$} & $1984^{13}$ & $\mathrm{~F}$ & 27 & + & - & uni & 0 \\
\hline & 1985 & $\mathrm{~F}$ & 15 & + & - & $\mathrm{bi}$ & +2 \\
\hline & 1985 & $\mathbf{M}$ & 14 & + & - & bi & $+3(\mathrm{RE}) /+5(\mathrm{LE})$ \\
\hline & 1986 & $\mathbf{F}$ & 15 & + & - & uni & +4 \\
\hline & & $\mathrm{F}$ & 26 & + & - & uni & -3 \\
\hline & 1986 & F & $\begin{array}{l}30 \\
56\end{array}$ & + & - & uni & $\begin{array}{l}+3 \\
-1\end{array}$ \\
\hline \multirow{2}{*}{$\begin{array}{l}\text { Burnier et al }{ }^{14} \\
\text { Mouillon } e t a l^{11}\end{array}$} & 1986 & $\mathrm{~F}$ & 48 & + & - & $\begin{array}{l}\text { bi } \\
\text { bi }\end{array}$ & $\begin{array}{l}-1(\mathrm{LE}) / 0(\mathrm{RE}) \\
-1(\mathrm{RE}+\mathrm{LE})\end{array}$ \\
\hline & & $\mathbf{F}$ & 12 & + & + & bi & $\begin{array}{r}+6 \\
0\end{array}$ \\
\hline \multirow[t]{4}{*}{ Rossenbaum $^{12}$} & 1988 & $\mathbf{F}$ & 43 & + & $+\ddagger$ & bi & +7 \\
\hline & & $\mathbf{M}$ & 13 & + & - & bi & +3 \\
\hline & & $F$ & 42 & + & $+\S$ & bi & +3 \\
\hline & & $\begin{array}{l}\mathbf{M} \\
\mathbf{F}\end{array}$ & $\begin{array}{l}54 \\
52\end{array}$ & $\begin{array}{l}+ \\
+\end{array}$ & $\begin{array}{l}- \\
-\end{array}$ & $\begin{array}{l}\text { bi } \\
\text { bi }\end{array}$ & $\begin{array}{l}+5 \\
<1\end{array}$ \\
\hline Present case & 1988 & $\mathrm{~F}$ & 66 & + & - & uni & $+5 \mathrm{LE} /+20(\mathrm{RE})$ \\
\hline
\end{tabular}

^ $\mathrm{Bi}=$ bilateral uveitis diagnosed at the same moment or with an interval of no more than two months between both eyes.

†Months before $(-)$, less than $(<)$, concurrent with $(0)$, or after $(+)$ AIN.

†ystoid maculopathy.

Pars planitis. to be responsible for this syndrome. Systemic disease and a drug induced nephritis have been excluded.

An immunological disorder accompanying or causing this syndrome is most likely since: (1) the interstitial infiltrate consists of lymphocytes; (2) a hypergammaglobulinaemia (IgG) is found in most cases; (3) the response to steroid treatment is favourable.

\section{CONCLUSION}

The oculorenal syndrome or TINU syndrome is probably of immunological origin; is accompanied by uni- or bilateral anterior uveitis, which may follow, concur with, or even precede the renal failure; and is most frequently seen in children and adult females, but can occur at any age as the present case illustrates.

We thank R Leysen, J Raes, and D Scheerlinck for their technical assistance.

1 Dobrin RS, Vernier RL, Fish AJ. Acute eosinophilic interstitial nephritis and renal failure with bone marrow-lymph node granulomas and anterior uveitis. A new syndrome. Am F Med 1975; 59: 325-33.

2 Guesry P, Loirat C. Néphrite tubulo-interstitielle aiguë et uvéite. In: Fournées parisiennes de pédiatrie. 1976; S: 187-97.

3 Kikkawa Y, Sakurai M, Mano T, Hirabayashi K, Kitagawa T. Interstitial nephritis with concomitant uveitis. Report of two Interstitial nephritis with concomitant

4 Van Acker KJ, Buyssens N, Neetens A, Lequesne M, Desmet N. Acute tubulo-interstitial nephritis with uveitis. Acta N. Acute tubulo-interstitial

5 Levy $M$. Néphropathies tubulo-interstitielles immunologiques. Néphrologie pédiatrique 1983; 3: 187-99.

6 Roth W, Laberke HG. Akute interstitielle Nephritis mit Iridocyclitis. Dtsch Med Wochenschr 1983; 108: 181-5.

interstitial nephritis by oral corticosteroids have been reported. ${ }^{1679-13}$ Two patients ${ }^{15}$ needed cytotoxic agents in addition to steroids for the control of the nephrotic syndrome. In some patients renal abnormalities improved spontaneously. ${ }^{+121415}$ The correlation between the improvement of renal function and corticosteroid administration suggests a beneficial effect of corticosteroids. However, there is no proof of their necessity. In no case has a relapse of the renal disease been observed, whereas the uveitis relapses frequently and after varying periods of time.

The aetiology of the TINU syndrome remains unknown. Classical causes of interstitial nephritis and/or uveitis (as may be shown by serological markers or by bacterial or viral cultures, toxic agents, etc) have not been shown 